EGG-NPR-10690

November 1990

\title{
TEMPERATURES AND HEAT FLOW IN INEL-GT1 AND WO-2 BOREHOLES, SNAKE RIVER PLAIN, IDAHO
}

by

\author{
David D. Blackwe11 \\ Department of Geological Sciences \\ Southern Methodist University \\ Dallas, Texas 75275
}

\section{DISCLAIMER}

\begin{abstract}
This report was prepared as an account of work sponsored by an agency of the United States Government. Neither the United States Government nor any agency thet eof, nor any of their employees, makes any warranty, express or implied, or assumes any legal ciability or responsibility for the accuracy, completeness, or usefulness of any information, apparatus, product, or process disclosed, or represents that its use would not infringe privately owned rights. Reference herein to any specific commercial product, process, or service by trade name, trademark, manufacturer, or otherwise does not necessarily constitute or imply its endorsement, recommendation, or favoring by the United States Government or any agency thereof. The views and opinions of authors expressed herein do not necessarily state or reflect those of the United States Government or any agency thereof.
\end{abstract}

\author{
Prepared for U.S. Department of Energy \\ office of New Production Reactors \\ Under DOE Idaho Field Office \\ Contract No. DE-AC07-76ID01570
}

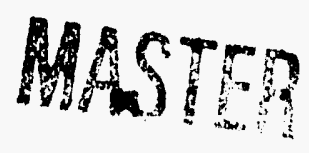


TEMPERATURES AND HEAT FLOW IN INEL-GT1, SNAKE RIVER PLAIN, IDAHO
A Report to

EG \& G, Idaho

Box 1625

Idaho Falls, Idaho

by

David D. Blackwell

Department of Geological Sciences

Southern Methodist University

Dallas, Texas 75275

November 10, 1990

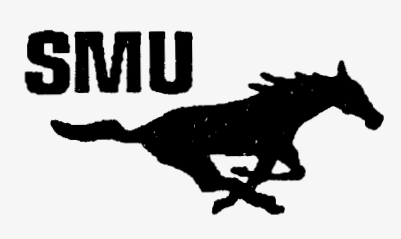




\section{TEMPERATURES AND HEAT FLOW IN INEL-GT1 \\ INTRODUCTION}

We have logged temperatures in the deep geothermal test at the INEL test site on the eastern Snake River Plains in Idaho (INEL-GT1) three times over a period of 8 years. The first logging was on $8 / 20 / 82$ when we reached a depth of $2100 \mathrm{~m}$. We were unable to get past the casing shoe at that depth. In $1983(7 / 25 / 83)$ we relogged the well with a centralizer on the temperature tool and got past the casing hanger to the end of our cable at $2870 \mathrm{~m}$. In both cases the logs were made at a $0.5 \mathrm{~m}$ recording interval, our finest depth increment of temperature measurement at that time. In 1990 we relogged the well for a third time and for the first time reached the bottom of the well at $3130 \mathrm{~m}$. In this $\log$ the temperatures were measured at $0.2 \mathrm{~m}$ intervals. The temperature-depth plots for the last two logs are compared in Figure 1 and the gradient logs for the three logs are compared in Figure 2. The differences in temperature are almost too small to see on the plot. The only significant differences are in the depth interval 700 to $1850 \mathrm{~m}$, a section of the hole with a number of fluid disturbances that will be described below.

\section{TEMPERATURE AND GRADIENT COMPARISONS}

To clarify the discussion the hole will be divided into sections for the purposes of discussion. These sections are listed in Table 1 and the characteristics of the gradient in each section are summarized. The average gradients of some intervals are listed in Table 2.

The temperatures and gradients for the two loggings in 1982 and 1983 are identical within the resolution of the temperature tool, even in the section of the hole that shows extreme fluctuations of gradient, 700 to $1850 \mathrm{~m}$. There is a data gap for the logging of 1990 between 2110 and $2205 \mathrm{~m}$ so this section will appear different in most of the plots and should be disregarded. The thermal conditions in the hole are generally conductive in the region 250 to $700 \mathrm{~m}$ and 1850 to $3150 \mathrm{~m}$. The gradient variations there are generally associated with thermal conductivity variations related to lithologic variations. The best heat flow is determined in this section of the well and will be discussed in a subsequent section of the report. 
The temperatures from the 1990 and 1983 loggings are compared in Figure 3. The temperatures are essentially the same above $1100 \mathrm{~m}$. Between 1100 and $1850 \mathrm{~m}$ the temperature differences range from about plus $1^{\circ} \mathrm{C}$ to minus $1^{\circ} \mathrm{C}$ in the areas of the well disturbed by fluid effects as described below. The background differences are about $0.2^{\circ} \mathrm{C}$ at $1850 \mathrm{~m}$ and systematically approach minus $1^{\circ} \mathrm{C}$ at the bottom of the $1983 \log$. The slight offset between 2100 and $2200 \mathrm{~m}$ is due to changing the range on a DVM. We believe that the differences below $1800 \mathrm{~m}$ are due to electrical leakage in the cable head in 1983 at temperatures above $100^{\circ} \mathrm{C}$. We are pursuing the discrepancy in more detail at this time, however, to resolve the cause or causes.

The fine scale variations of gradient (the noise in the gradient plots, see Figure 4) are associated with small convection cells in the fluid column related to the decrease in density of water with depth due to the positive geothermal gradient. The greatest noise is in the interval 850 to $1000 \mathrm{~m}$ where the gradient is highest and the fluctuations are lowest in the interval 1600 to $1820 \mathrm{~m}$ where the gradient is lowest. For the gradient of $40^{\circ} \mathrm{C}$ typical of much of the hole the noise is lower in the section of the hole that is $95 / 8^{\prime \prime}$ in diameter than in the larger sections of the hole above and below. The decrease in the gradient in the bottom of the hole is an end effect of the bottom of the hole.

A summary of several of the geophysical logs for the well are shown in Figure 5. The plotted curves are based on $6.1 \mathrm{~m}(20 \mathrm{ft})$ averages of the original open hole logs used by Williams (1981) in a study of the thermal conductivity of the well. This study will be discussed in more detail in a subsequent section. We do not have original copies of the logs at this time, so the comparisons in this discussion will refer to the logs as displayed in Figure 5. The logs shown include natural gamma-ray, travel time (displayed as velocity), and density (from the gamma-gamma $\log$ ). The $6 \mathrm{~m}$ averages were prepared to smooth out the local fluctuations due to hole size so the areas where there are obvious hole size effects on the logs (areas of low velocity) are major zones of hole enlargement. Many of these areas coincide with areas of anomalous temperature gradients.

İNEL-GT1 Heat Flow p.3 
Convective Disturbances The temperatures and gradients depart from conductive behavior in a significant way in the interval between 700 and $1850 \mathrm{~m}$. The interpretation of this region is shown diagrammatically in Figure 6. The gradients in the interval between 750 and about 1100 $\mathrm{m}$ are disturbed by two major areas of moving water in the rocks around the drill hole. There appears to be water moving from higher elevation to lower elevation past the drill hole in the ash flows directly below the thin layer of sediments encountered in the depth interval 670 to $750 \mathrm{~m}$. The evidence for this behavior is the negative excursion of the temperatures in this interval relative to the interpolation of the temperature-depth curve through this region. This general downward movement past the hole is mirrored by a similar upward movement past the hole in the depth interval 1000 to $1100 \mathrm{~m}$. The temperatures in areas of the hole adjacent to the zones of water flow have changed temperature significantly between loggings (Figure 4, down about $0.1^{\circ} \mathrm{C}$ in the upper zone and up about $0.1^{\circ} \mathrm{C}$ in the lower zone), indicating the disturbed nature of the temperatures in these areas.

The most obvious disturbance to the temperatures and gradients in the well is in the depth interval 1580 to $1850 \mathrm{~m}$. The shape of the upper part of this disturbance is a classic example of up-flow in the well bore between two water bearing zones connected by the drilling (in this case the water is flowing in the annulus outside the $95 / 8^{\prime \prime}$ casing). The bottom part of this disturbance is a classic example of down-flow in the well bore between two water bearing zones connected by the drilling (in this case also the water is flowing in the annulus outside the $95 / 8^{n}$ casing). The geophysical logs show evidence of porous zones at 1600 and $1820 \mathrm{~m}$ that may be the acceptor zones. The donor zone (or zones) is not so obvious from the available log data although the original logs need to be examined again for evidence of the location of this zone. It should be in the 1680 to $1720 \mathrm{~m}$ depth interval. The temperature in this $270 \mathrm{~m}$ interval has decreased about $0.7^{\circ} \mathrm{C}$ in the time interval between loggings again indicating that the temperatures in this portion of the hole are relatively unstable.

The behavior of the temperatures and gradients in the interval 1100 to $1540 \mathrm{~m}$ is the most puzzling in the whole hole. The gradients vary by too great an amount to be explained by 
simple conductive heat transfer. The gradient pattern on the logs of $8 / 20 / 82$ and $7 / 25 / 83$ was identical, so the effects do not appear to be transient. The pattern was similar, although slightly more simple on the $1990 \mathrm{log}$. The temperatures changed the most between the loggings of 1983 and 1990 in this interval, being plus about $1{ }^{\circ} \mathrm{C}$ at $1380 \mathrm{~m}$ and minus about the same amount at $1450 \mathrm{~m}$. The geophysical logs show evidence of major hole enlargements at both depths. The pattern in 1990 between 1380 and $1460 \mathrm{~m}$ appears to be a miniature case of the interval between 1600 and $1800 \mathrm{~m}$ described above. Perhaps flow began in the well between the two logging periods. The zone between 1280 and $1320 \mathrm{~m}$ is enlarged. Blackwell et al. (1981) found that areas with hole enlargements in a geothermal well in Oregon were characterized by areas of sigmoidal gradient-depth plots. Thus some combination of intrawell flow and hole size complications may explain the complicated gradient pattern in this region. The average gradient in this interval is about the same as in the rest of the hole so the heat flow does not appear to be affected (see discussion below). The Schlumberger logs need to be examined in conjunction with this new temperature data for a final evaluation of the controls on the temperature and gradients in this interval of the well.

\section{THERMAL CONDUCTIVITY AND HEAT FLOW}

Several cores were obtained during the drilling of the well. Thermal conductivity values were measured on samples of these cores at room temperature and the temperature corrected values were used to calculate a heat flow for the hole by Brott et al. (1981; the results are also discussed by Blackwell, 1989). Williams (1981) also measured the P-wave velocity as a function of pressure on these core samples and developed empirical relationships relating thermal conductivity, P-wave velocity and some of the well log properties. Plots of these predicted thermal conductivity values at room temperature conditions for four different relationships are illustrated in Figure 7. For the purposes of this report the curves are not significantly different and only curve THCl was used in the analysis. The thermal conductivity was calculated from the $6 \mathrm{~m}$ average velocity log for intervals divided into lithologic sections using the lithology and natural gamma-ray information using the relationship

INEL-GT1 Heat Flow p.5 


$$
\mathrm{TC}=-0.36+1.38 * \mathrm{Vp}
$$

for the section of the hole in rhyolite and by the relationship

$$
\mathrm{TC}=-0.26+0.86^{*} \mathrm{Vp}
$$

for the section of the hole in basalt..

The gradient, thermal conductivity, and heat flow values for the well were averaged over a $100 \mathrm{~m}$ interval to smooth out the smaller scale fluctuations in the values and are shown in Figure 8. The thermal conductivity values shown are corrected for temperature effects so they should closely reflect in situ values. The heat flow panel shows that the bottom of the well has an average heat flow of about $100 \mathrm{mWm}^{-2}$.

A better way to evaluate the heat flow for the well is to prepare a plot of the sum of the thermal resistance down the well and the corresponding temperature (Figure 9). The thermal resistance is calculated from the inverse of the average thermal conductivity for each $6.1 \mathrm{~m}$ interval from Figure 7 (after temperature correction) multiplied times 6.1 meters and added to the preceding value representing the sum to the preceding depth (or temperature). The advantage of this form of the calculation is that the slope of the straight line between temperature and thermal resistance is the heat flow for that interval. The second and third panels in Figure 9 show a straight line fit for the intervals 21 to $137^{\circ} \mathrm{C}$ and 100 to $137^{\circ} \mathrm{C}$ respectively. The slopes of the lines are 99 and $107 \mathrm{mWm}^{-2}$ respectively.

The best heat flow for the hole is the $107 \mathrm{mWm}^{-2}$ value. This value agrees with the heat flow at USGS-2a and is determined for the portion of the INEL-GT1 well below the sections of the hole disturbed by water flow outside the well bore (above about $1100 \mathrm{~m}$ ). The line representing this heat flow value passes through the midpoints of the disturbances associated with the intrabore water flow zones below $1200 \mathrm{~m}$ so the inference that they represent disturbances related to the connection of fractures by the drill hole, and $\mathrm{t}$ t $\mathrm{t}$ natural flow, is reinforced. There appears to be a small net cooling of the upper part of the well, but the effect is most pronounced above $700 \mathrm{~m}\left(40^{\circ} \mathrm{C}\right)$. This may be real, or it may be due to an incorrect estimation of the thermal conductivity of the basalts in this part of the well. 
TABLE 1. CHARACTERISTIC GRADIENT INTERVALS

\begin{tabular}{cll} 
INTERVAL (METERS) & TYPE OF GRADIENT & CATEGORY \\
\hline & & \\
$0-100$ & & Air-above water table \\
$100-240$ & Near Zero & Snake River Plain aquifer \\
$240-700$ & 40 to $60^{\circ} \mathrm{C} / \mathrm{km}$ & Dominantly Conductive \\
$700-1200$ & Negative to $80^{\circ} \mathrm{C} / \mathrm{km}$ & Water flow past hole \\
$1200-1580$ & Fluctuating & Hole size (?) and water flow \\
$1580-1850$ & High to Isothermal & Intrahole water flow \\
18503100 & $40 \pm 5^{\circ} \mathrm{C} / \mathrm{km}$ & Conductive \\
$3100-3150$ & Low & Hole end effect
\end{tabular}

TABLE 2. AVERAGE GRADIENTS FOR SECTIONS

DEPTH $(m)$

$250-3120$

$1880-3120$

$250-760$

$760-1580$

$760-1880$

$1580-1880$
GRADIENT AND S.E. $\left({ }^{\circ} \mathrm{C} / \mathrm{km}\right)$

$43.6 \pm 0.1$

$44.4 \pm 0.1$

$52.0 \pm 0.1$

$41.9 \pm 0.2$

$40.9 \pm 0.2$

$28.6 \pm 0.7$ 


\section{Figure Captions}

Figure 1. Temperature-depth and gradient-depth curves for $9 / 22 / 90$ log. 1 meter average gradients are plotted. There is a data gap between 2110 and $2205 \mathrm{~m}$.

Figure 2. Comparison of gradient-depth measurements for the logs of $9 / 22 / 90,7 / 25 / 83$, and $8 / 20 / 82$. 1 meter average values are plotted at each meter.

Figure 3. Temperature difference for $9 / 22 / 90$ and $7 / 25 / 83$ logs. Difference plotted at each 0.5 m.

Figure 4. Gradient difference for $9 / 22 / 90$ and $7 / 25 / 83$ logs. Difference plotted at each $0.5 \mathrm{~m}$.

Figure 5. Plot of natural gamma-ray, P-wave velocity, and density (gamma-gamma) log values from Schlumberger open hole logs. The plotted values are averaged over $20 \mathrm{ft}$ $(6.1 \mathrm{~m})$ intervals (after Williams, 1981). The gamma-gamma log was not run aboie $1085 \mathrm{~m}$.

Figure 6. Schematic diagram of the nature of fluid disturbances to the well.

Figure 7. Plot of calculated thermal conductivity based on several empirical relationships between thermal conductivity and various well log parameters (Williams, 1981). Values are not corrected for in situ temperatures.

Figure 8. Plot of $300 \mathrm{ft}(90 \mathrm{~m})$ average geothermal gradient, thermal conductivity (corrected for temperature effects), and heat flow.

Figure 9. Plot of thermal resistance as a function of temperature for the well. Lines representing least squares fits to the sections of the curve between 21 and $137^{\circ} \mathrm{C}$ and 100 and $137^{\circ} \mathrm{C}$ are shown in panels 2 and 3 respectively. 


\section{REFERENCES CITED}

Blackwell, D.D., Regional implications of heat flow of the Snake River Plain, northwestern United States, Tectonophysics, 164, 323-343, 1989

Blackwell, D.D., C.F. Murphey, and J.L. Steele, Heat flow and geophysical log analysis for OMF-7A geothermal test well, Mount Hood, Oregon, p. 47-56, in Geology and Geothermal Resources of the Mount Hood Area. Uregon, ed G.R. Priest and B.F. Vogt, Oregon Dept. Geology and Min. Industries Special Paper 14, 100 pp., 1981

Brott, C.A., D.D. Blackwell, and J.P. Ziagos, Thermal and tectonic implications of heat flow in the eastern Snake River Plain, Idaho, L. Geophys. Res, 86, 11709-11734, 1981.

Williams, J.W., In situ thetinal conductivity measurement from geophysical well logs in the eastern Snake River Plain, unpublished M.S. Thesis, Southern Methodist University, Dallas, Texas, 79 pp., 1981. 


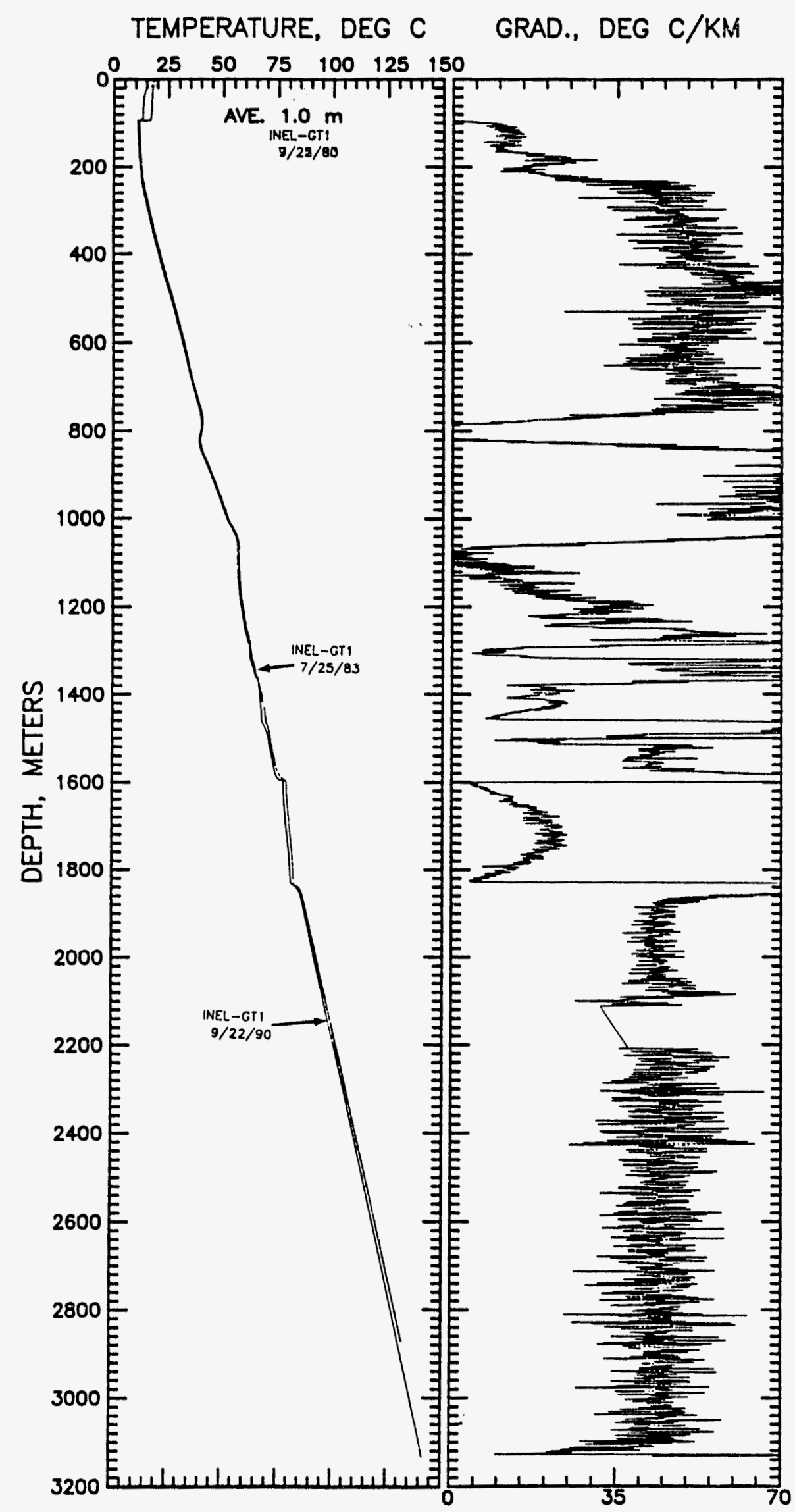

Fig 1 


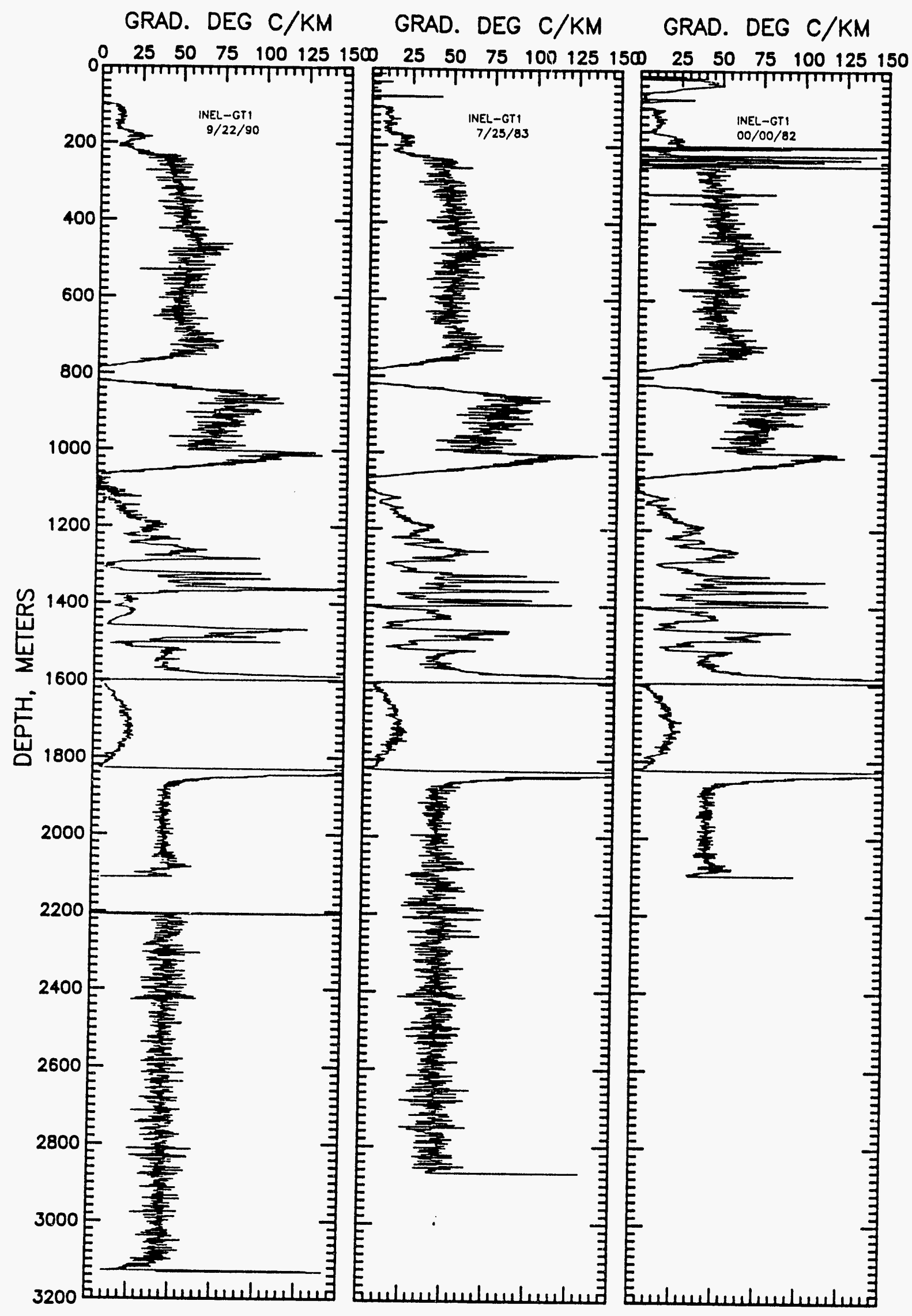

Fig. 2 


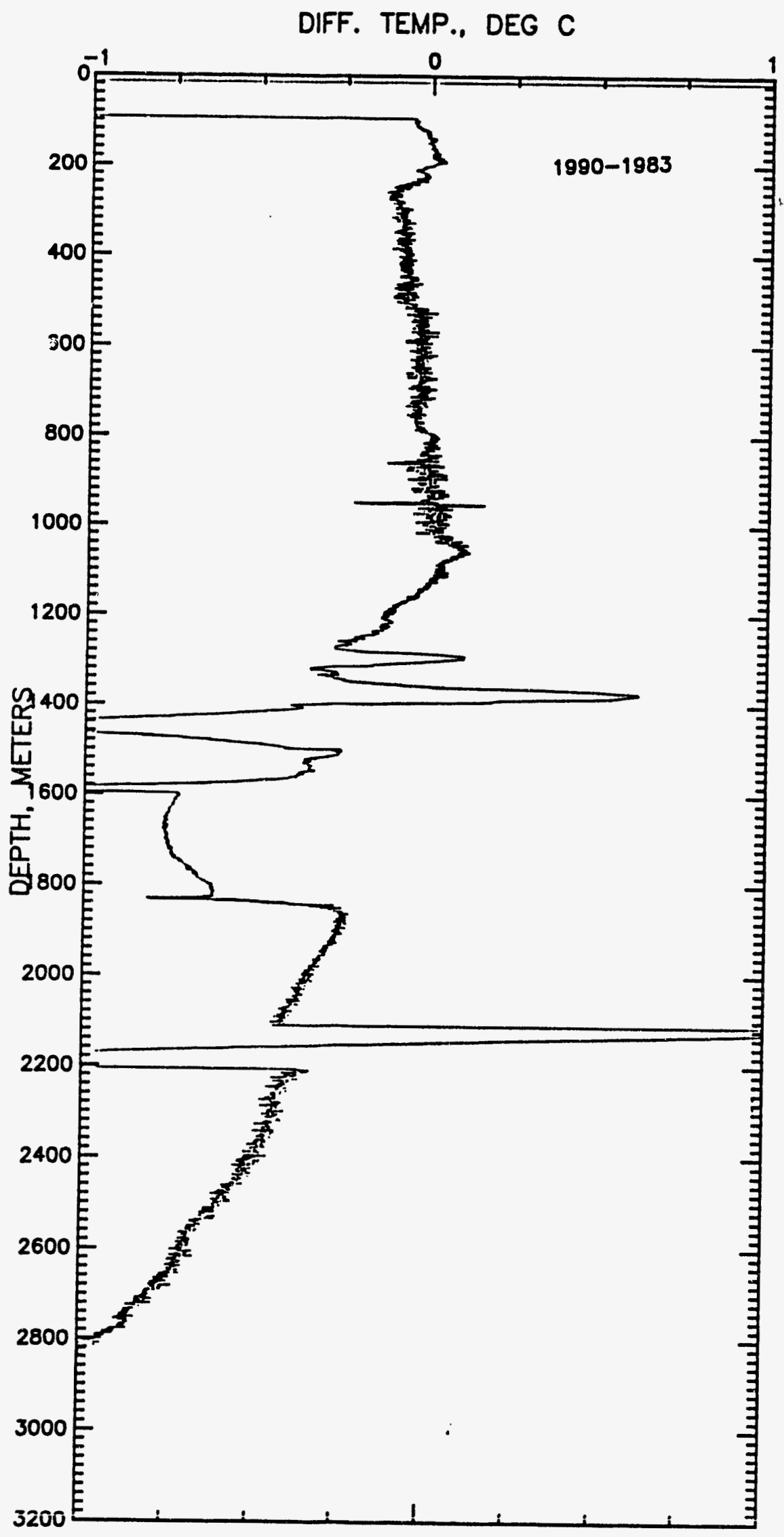

Fiy 3 


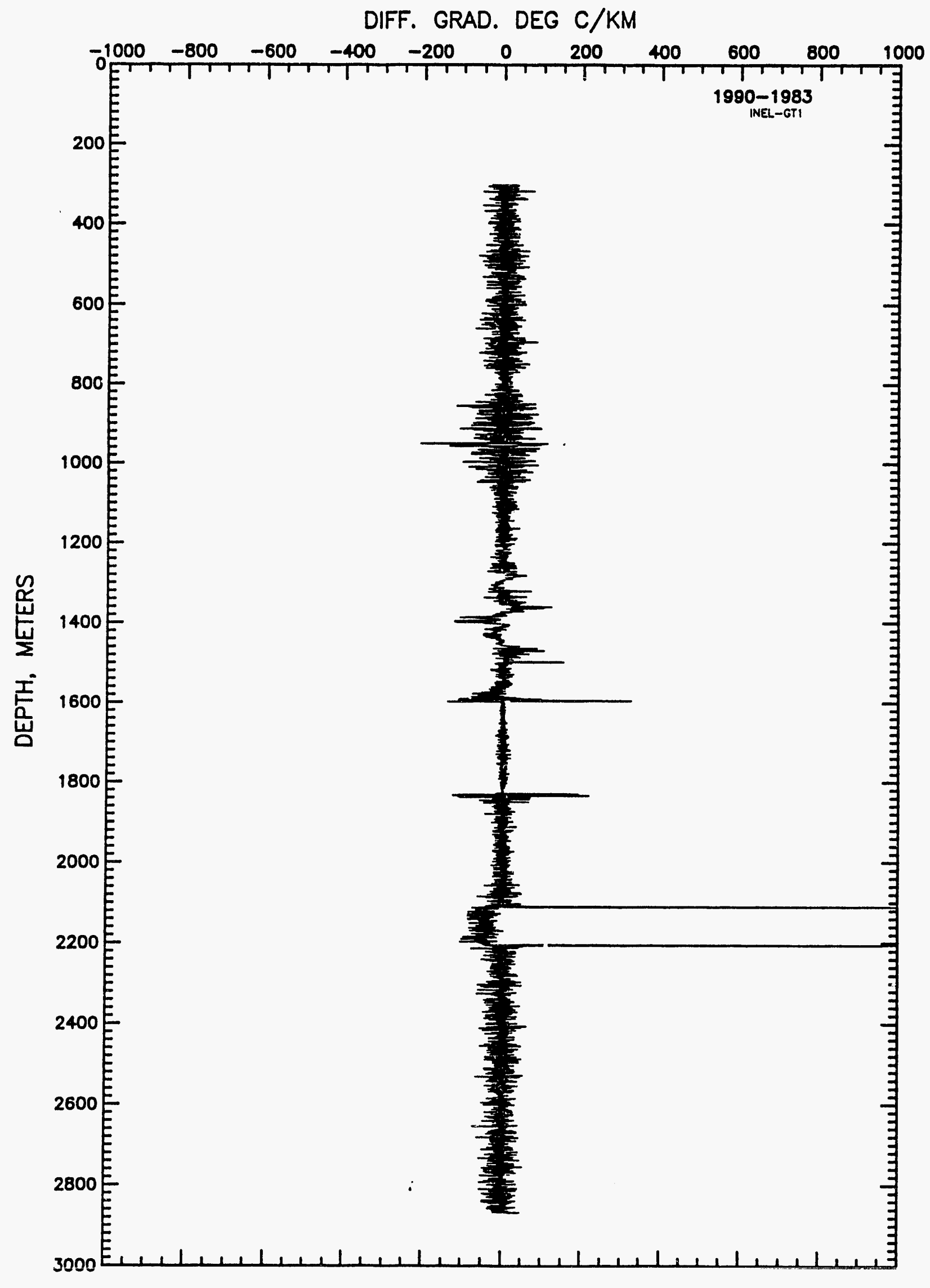

Fig. 4 


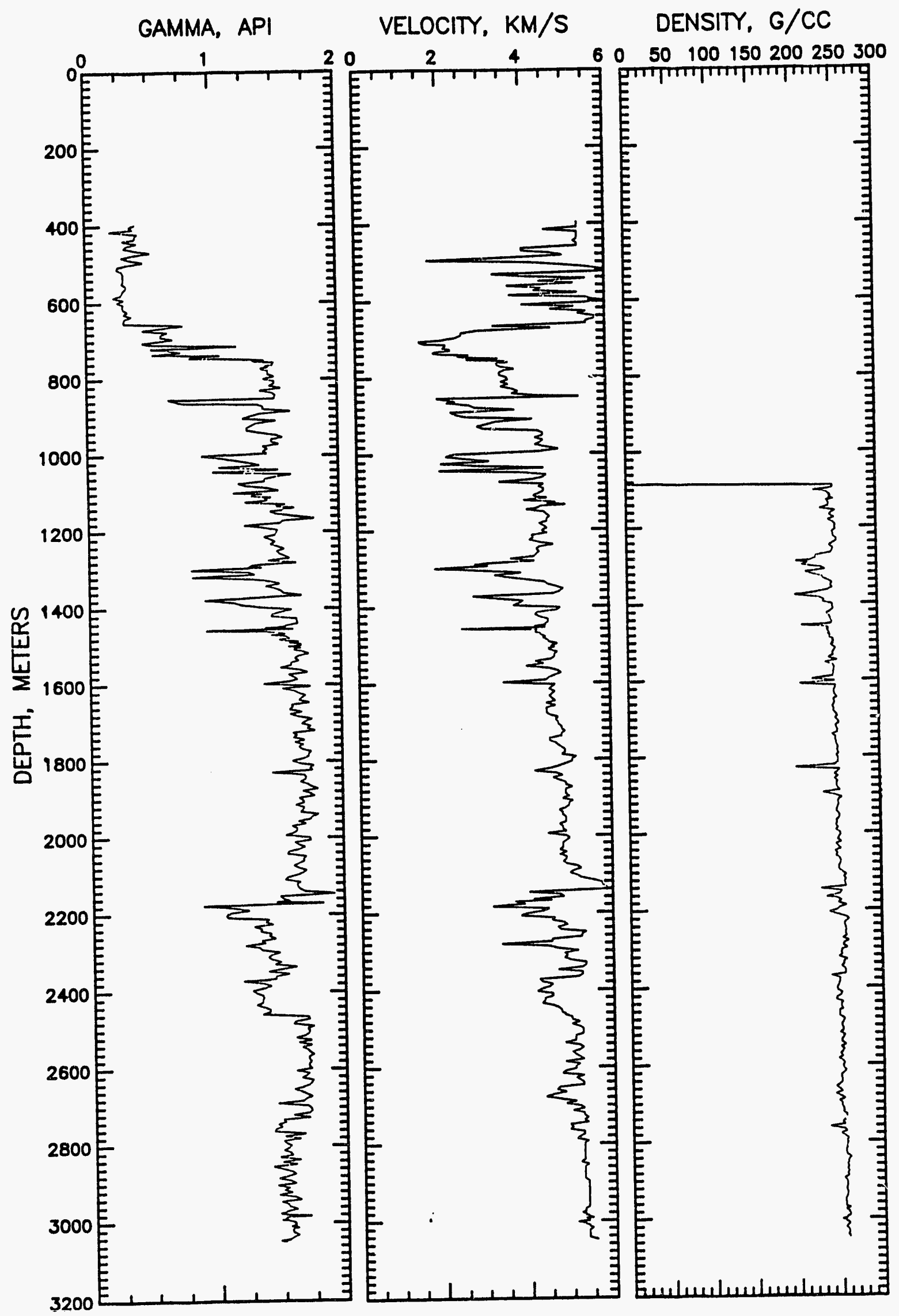

Fig 5 


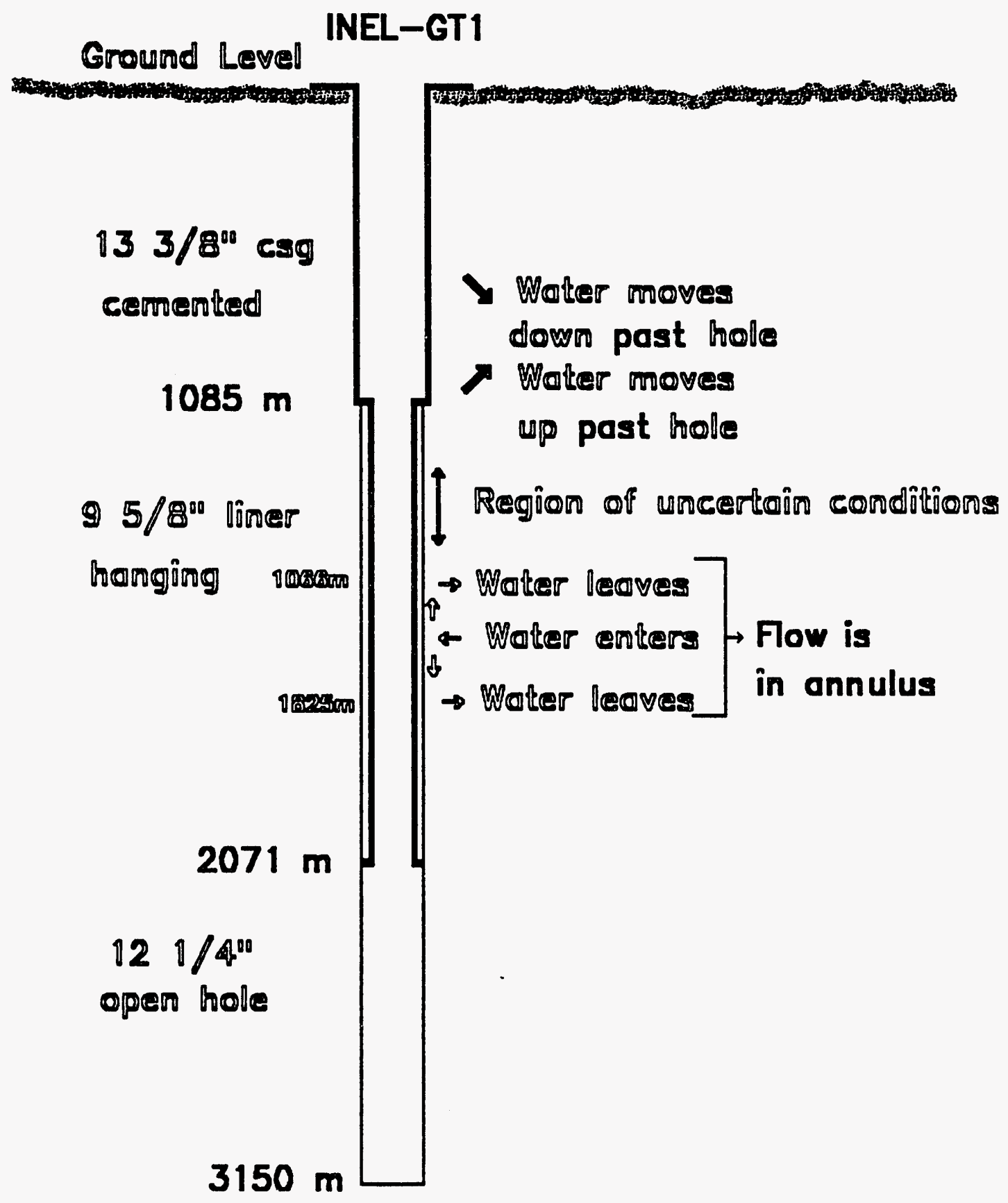




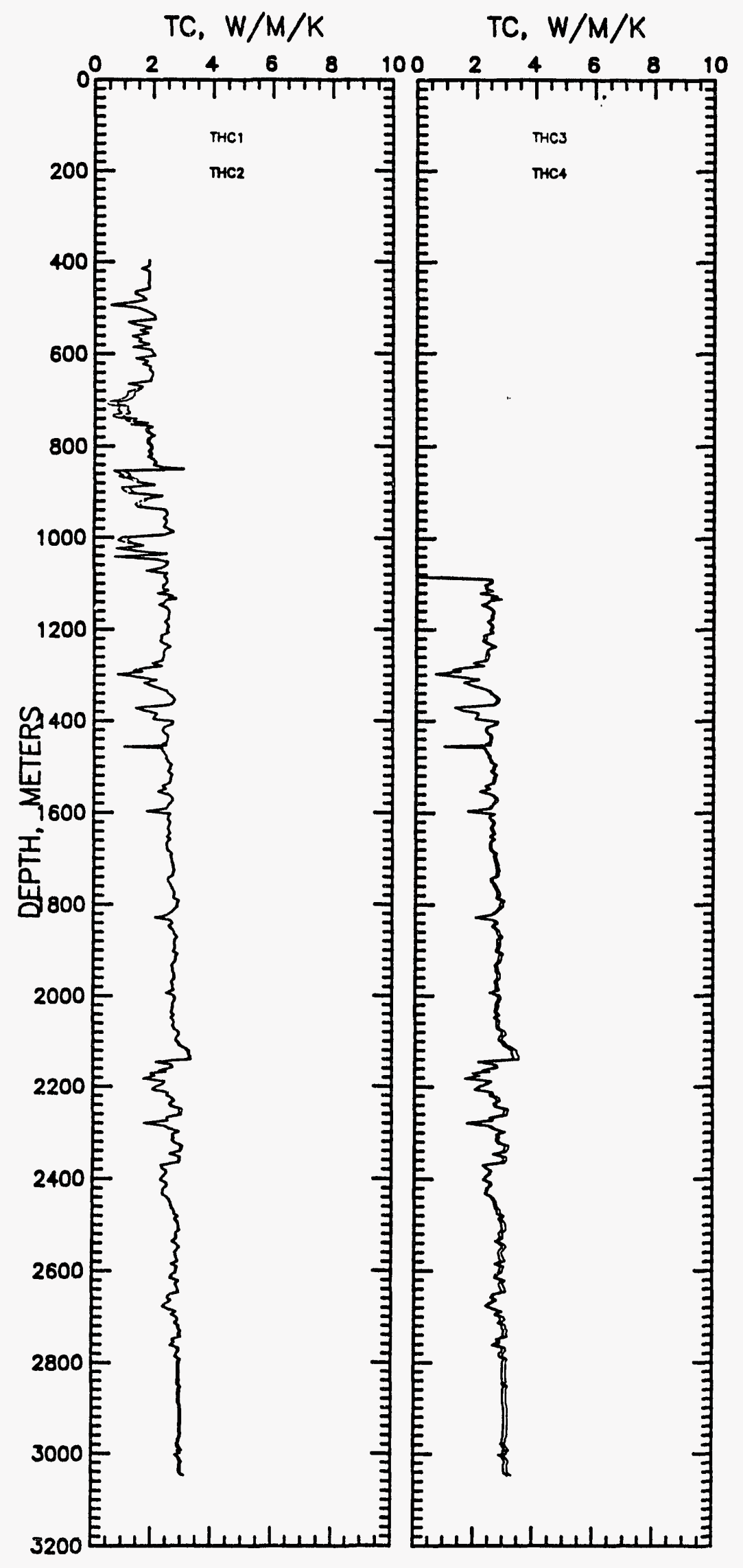

Fig. 7 


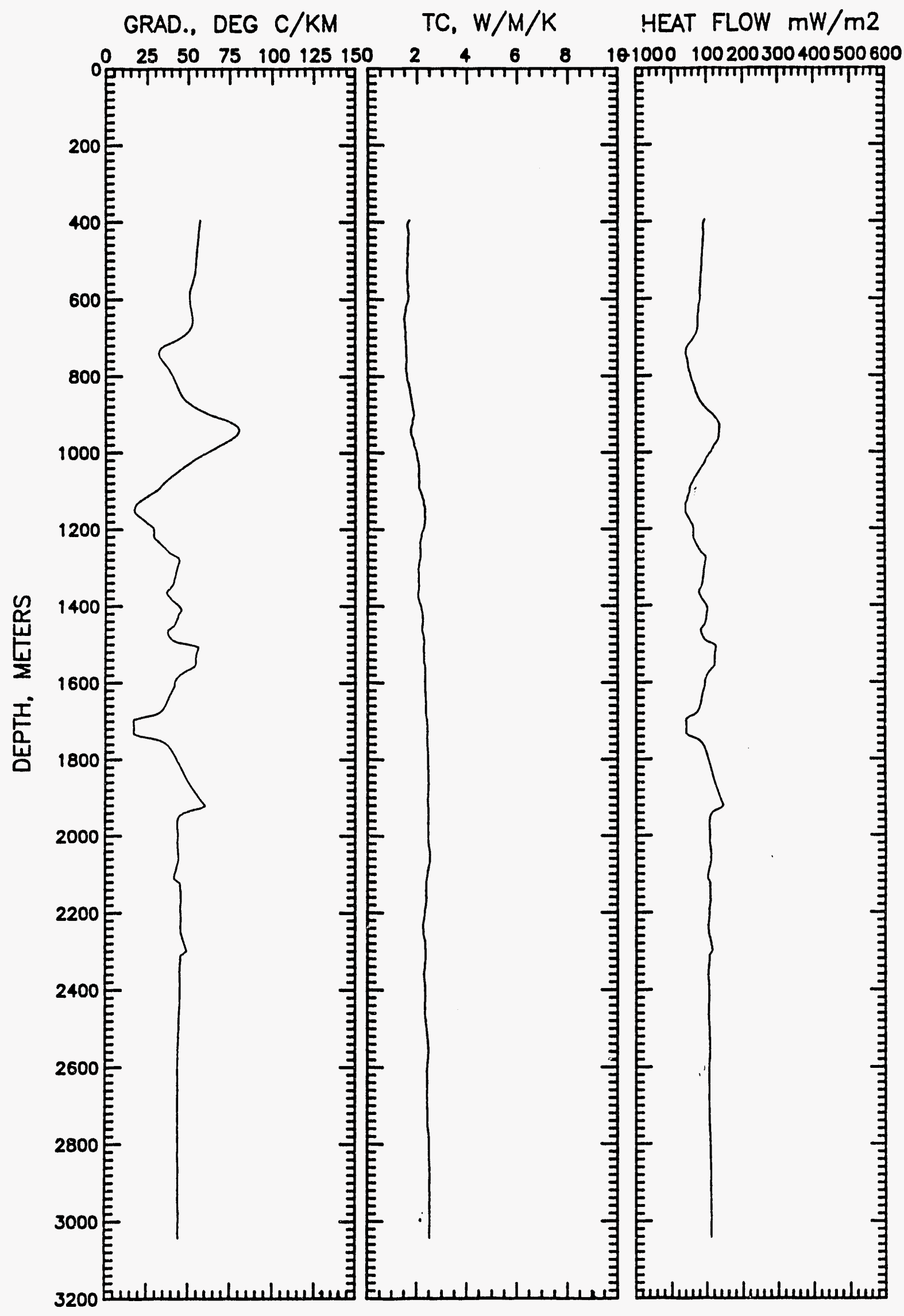

Figs 


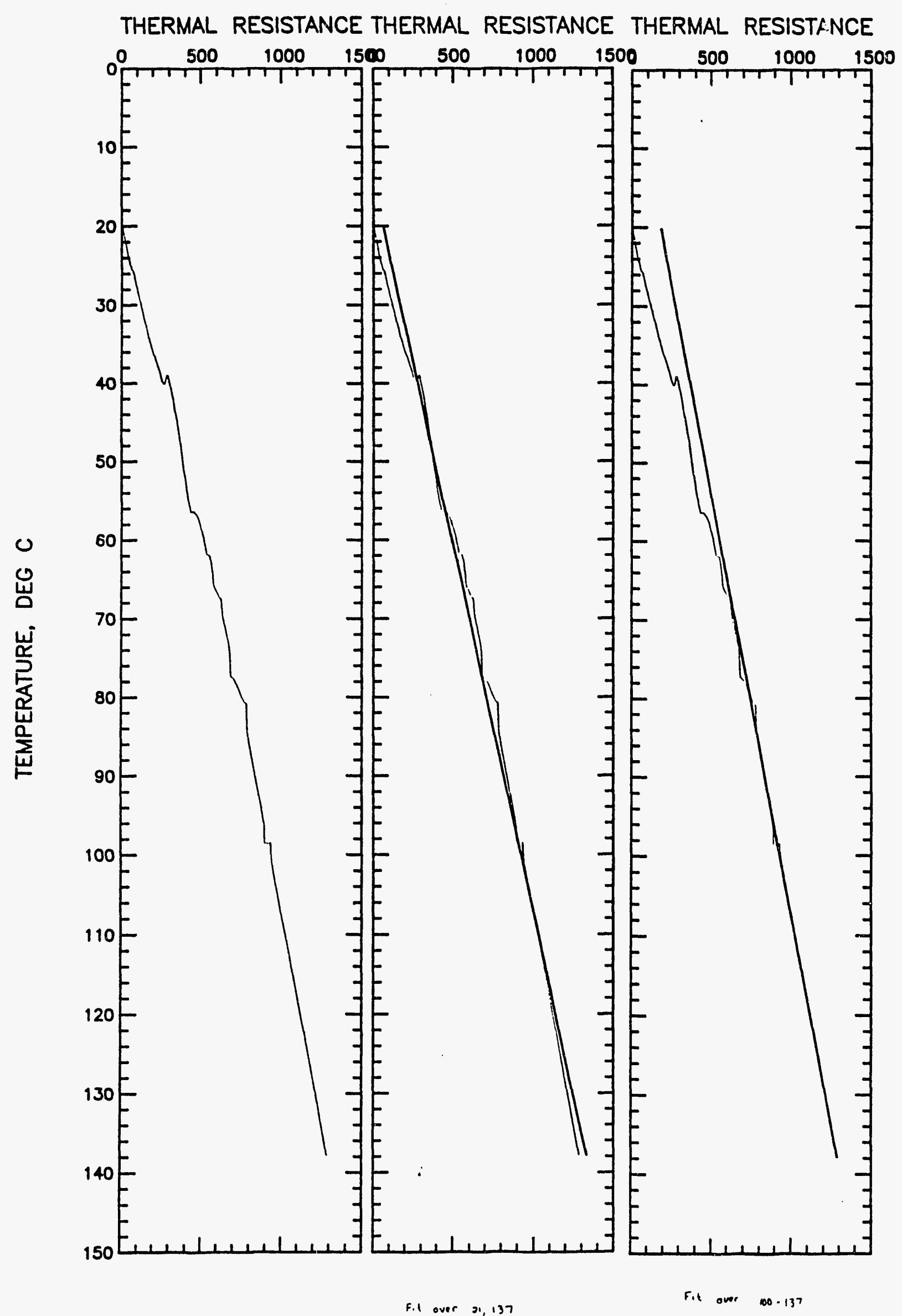

Fig. 9 
Aug. 18, 1992

Dick,

The log looks good for the WO-2 well. There are definitely still some drilling artifacts left, but the character of the log is much clearer. There was a lot of fluid loss into the $550 \mathrm{~m}$ region - there is still a residual positive disturbance there in fact. The average gradient in the $550-1200 \mathrm{~m}$ depth interval is $70-80$ degrees $\mathrm{C} / \mathrm{km}$. It appears to be lower below that interval. Will have to do the conductivities to see what the relative heat flow values are. The water table is very shallow! Apparently the deep zones have higher heads than the shallow zones. The thermal effect of the aquifer stops quite abruptly at $550 \mathrm{~m}$ apparently though.

Best,

Dave 


\section{TEMPERATURE LOGS OF NPR DRILL HOLE W0-2}

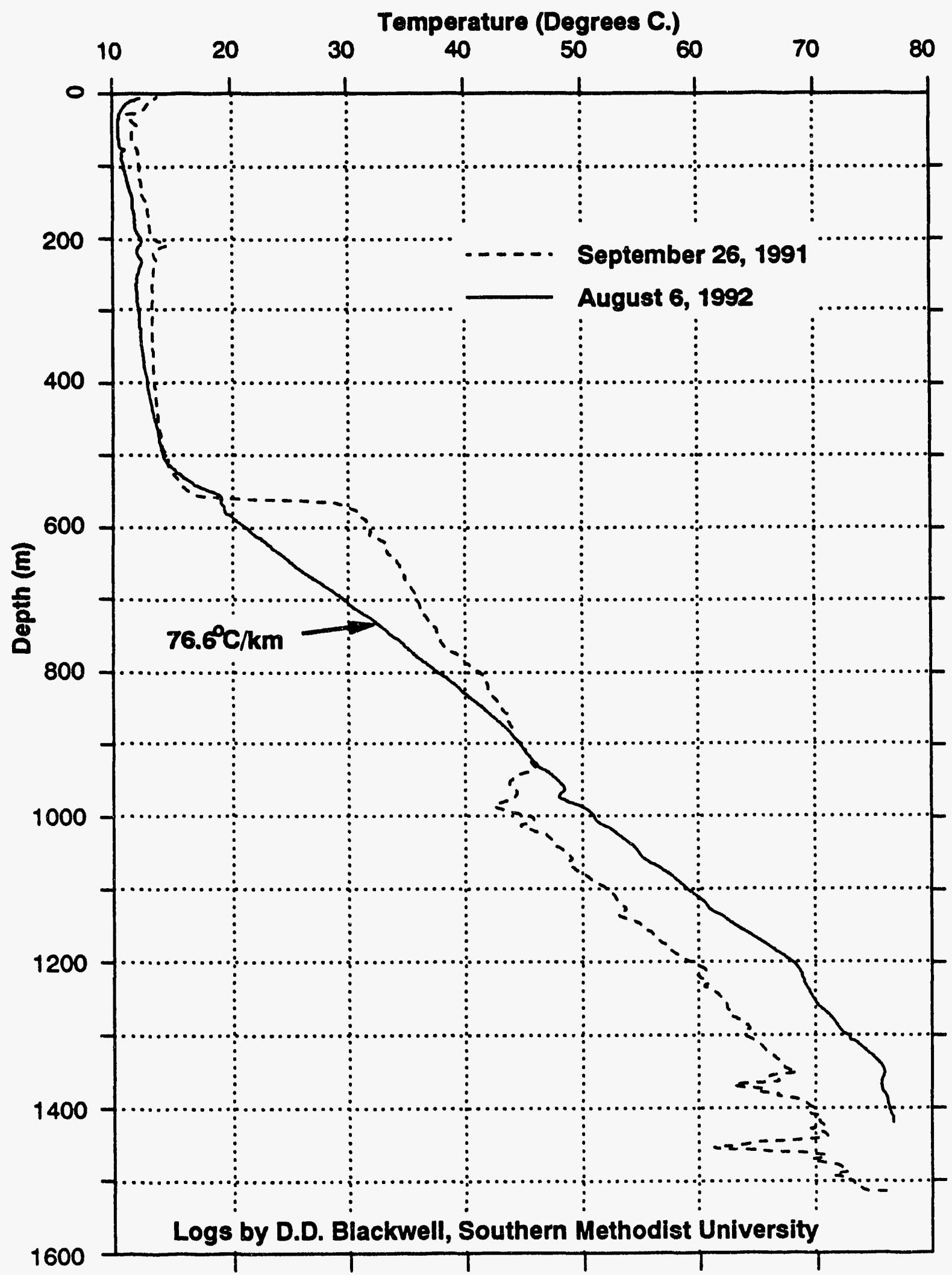


TEMPERATURE, DEG C

GRAD. DEG $C / K M$

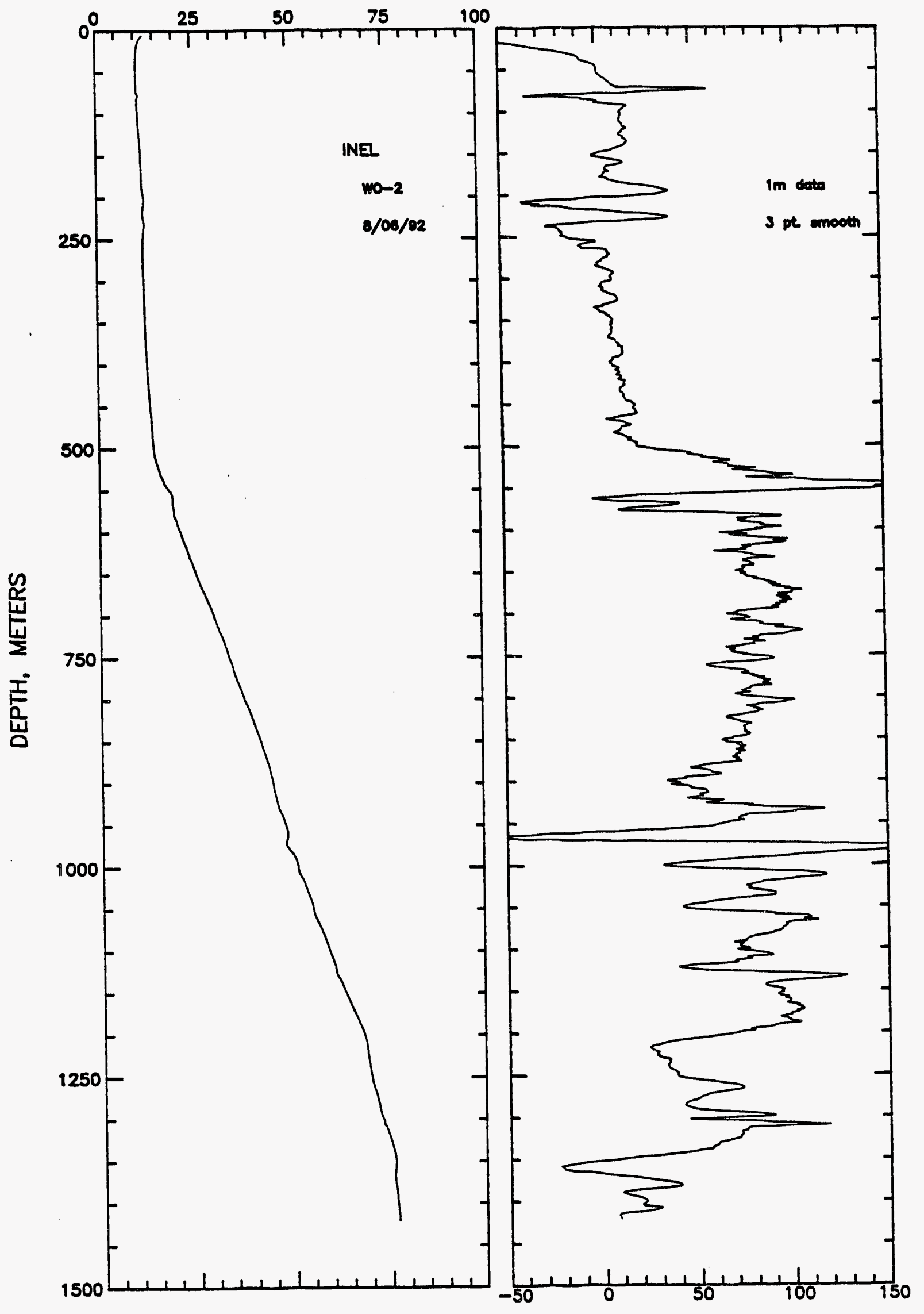




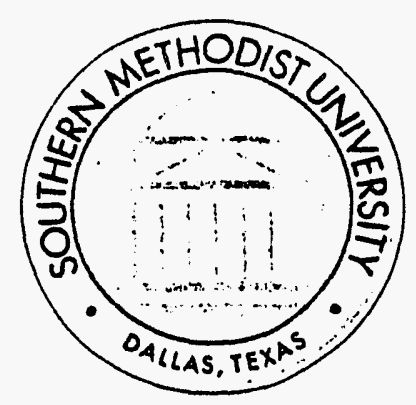

Dr. Richard Smith

EG \& G ldaho, inc.

PO Box 1625, MS 2107

Idaho Falls, Idaho 83415-2082

Dear Dick:

Here is a temperature-depth plot of the new hole and a floppy disk with the temperature data in digital format ian ASCII file with depth and temperature in two columns). Of course the temperatures are disturbed in a major way by the drilling disturbance, but the overall trends are clear. I have plotted the INEL-GT1 well temperature log as a comparison to the new log. There is a major zone of downflow, probably just in the well bore, between about 250 and $550 \mathrm{~m}$. The major reentrants in the log below that depth are associated with zones of major fluid loss during the drilling process. The gradient looks like it will be dominated by conduction over most of the depth range of the log, so I think that we will get a good heat flow from the well when it reaches equilibrium.

The major points as I see them now are: the temperatures are slightly higher at $1500 \mathrm{~m}$ than in GT1; the gradient may be mostly conductive below 550 $\mathrm{m}$ (and above as well if the hole were grouted to stop the down flow); the at-depth effect of the Snake Plain aquifer on the temperatures appears to be similar to or less than at the USGS core hole between the buttes (the temperature there is less than $20^{\circ} \mathrm{C}$ at almost $700 \mathrm{~m}$ ). The hole will cool off significantly in the 700 to $1000 \mathrm{~m}$ region as it reaches equilibrium. Thus the gradient will probably be higher than the GT1 well. However, because the thermal conductivity of the basalts may be less than the rhyolites, the heat flow may be similar to possibly lower than the heat flow at the GT1 site. Obviously we can't tell until we make thermal conductivity measurements and equilibrium temperature measurements. Nonetheless I think the result will strengthen the conclusion that the center of the Snake River Plain is hotter that its surroundings.

Give me a call if you have questions.

Sincerely yours<smiles>C[13CH]=[13C]</smiles>

David D. Blackwell

Hamilton Professor of Geophysics

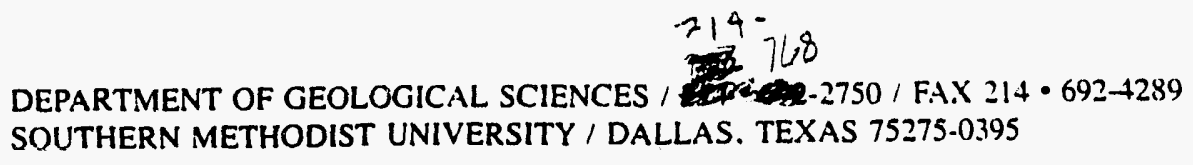


October 1, 1991

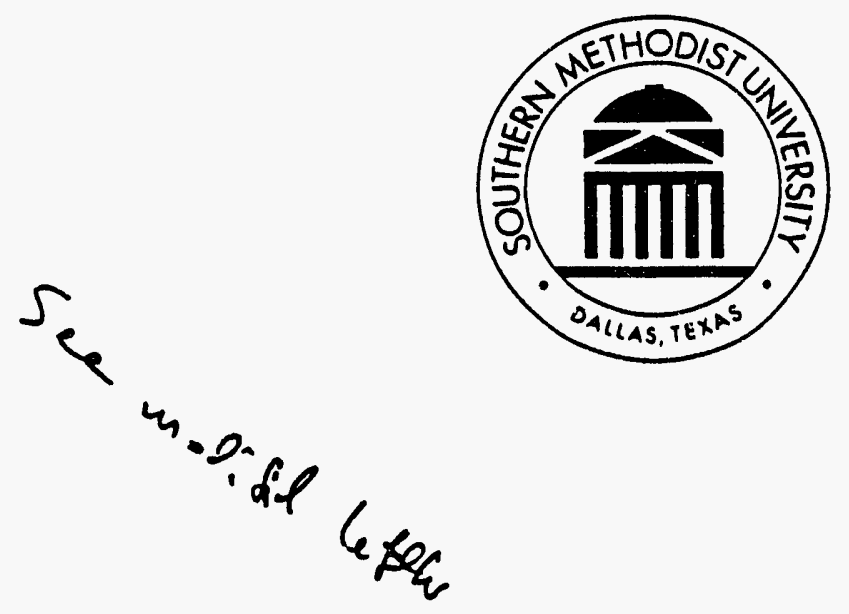

Dr. Richard Smith

EG \& G Idaho, inc.

PO Box 1625, MS 2107

Idaho Falls, Idaho 83415-2082

\section{Dear Dick:}

Here is a preliminary temperature-depth plot of the new hole. Of course the temperatures are disturbed in a major way by the drilling disturbance, but the overall trends are clear. I have plotted the INEL-GT1 well temperature log as a comparison to the new log. There is a major zone of downflow, probably just in the well bore, between about 250 and $550 \mathrm{~m}$. The major reentrants in the log below that depth are associated with zones of major fluid loss during the drilling process. The gradient looks like it will be dominated by conduction over most of the depth range of the log, so I think that we will get a good heat flow from the well when it reaches equilibrium.

The major points as I see them now are: the temperatures are slightly higher at $1500 \mathrm{~m}$ than in GT1; the gradient may be mostly conductive below 550 $m$ (and above as well if the hole were grouted to stop the down flow); the at-depth effect of the Snake Plain aquifer on the temperatures appears to be less than at the USGS core hole between the buttes (the temperature there is less than $20^{\circ} \mathrm{C}$ at almost $700 \mathrm{~m}$ ). The bottom hole temperature implies that the heat flow will be similar to or higher than the heat flow at the GT1 site. This result would strengthen the conclusion that the center of the Snake River Plain is hotter that the surroundings.

Give me a call if you have questions.

Sincerely yours

$y$ are

David D. Blackwell

Hamilton Professor of Geophysics 
TEMPERATURE, DEG C

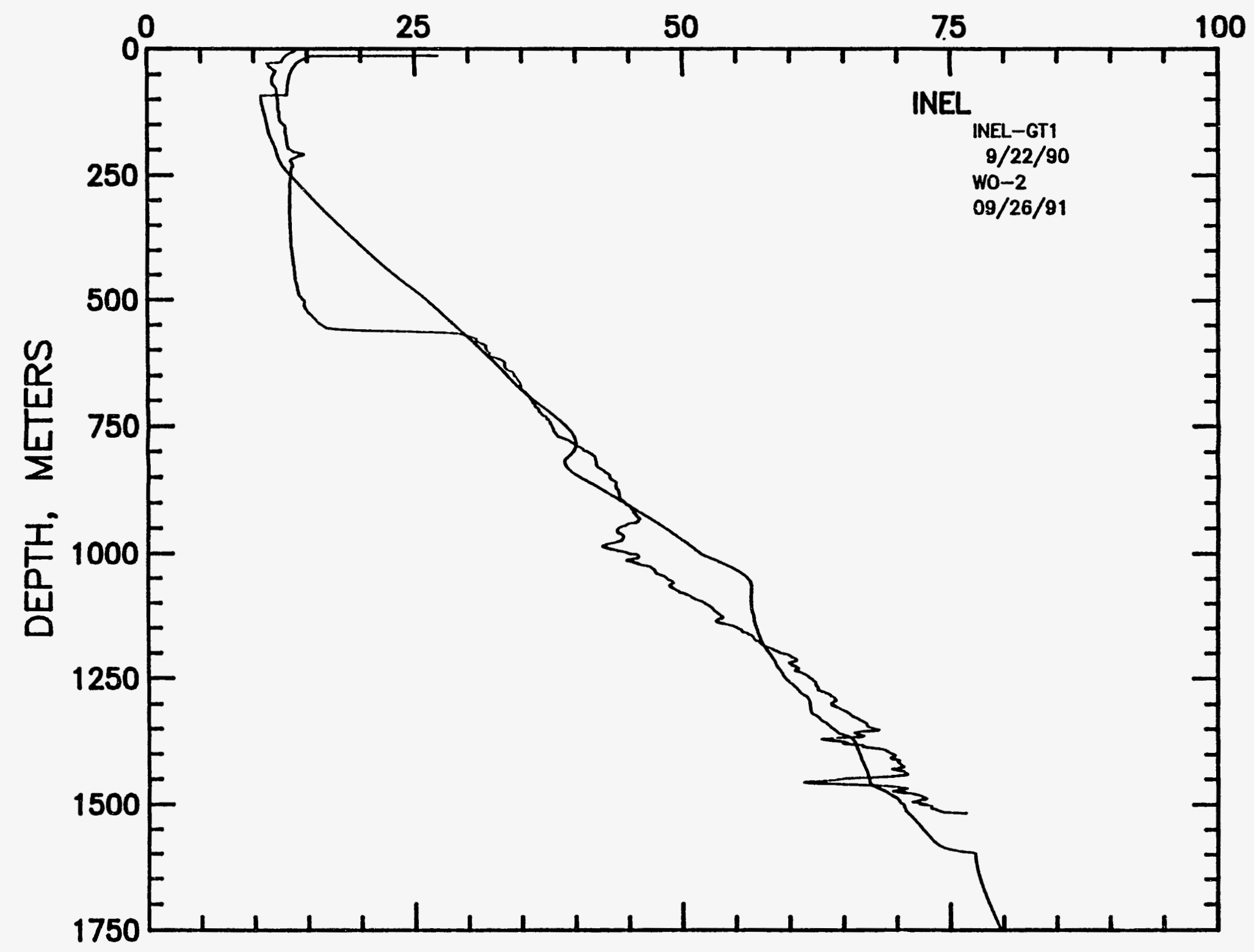




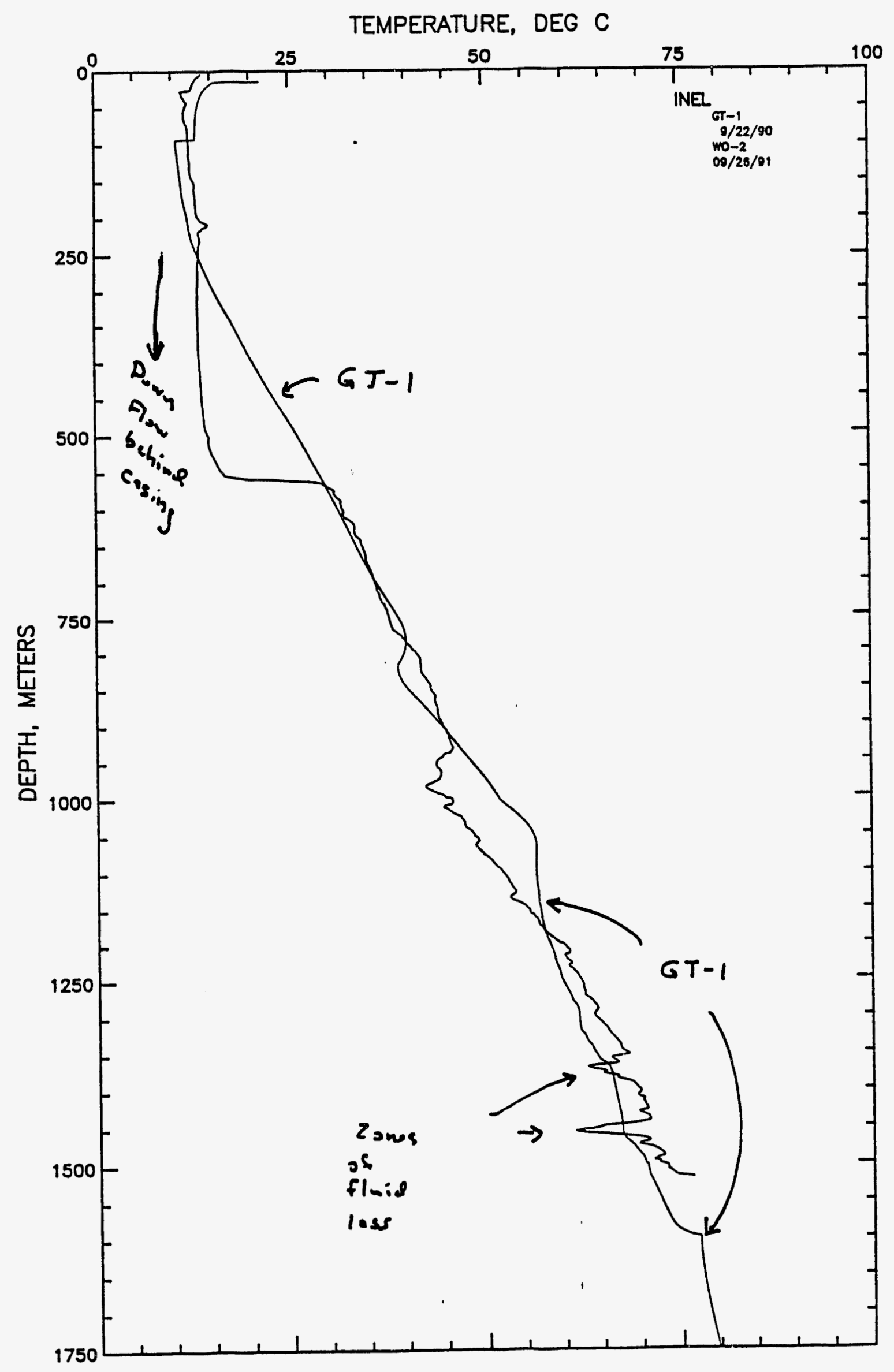


TEMPERATURE, DEG.C GRADIENT DEG C/KM

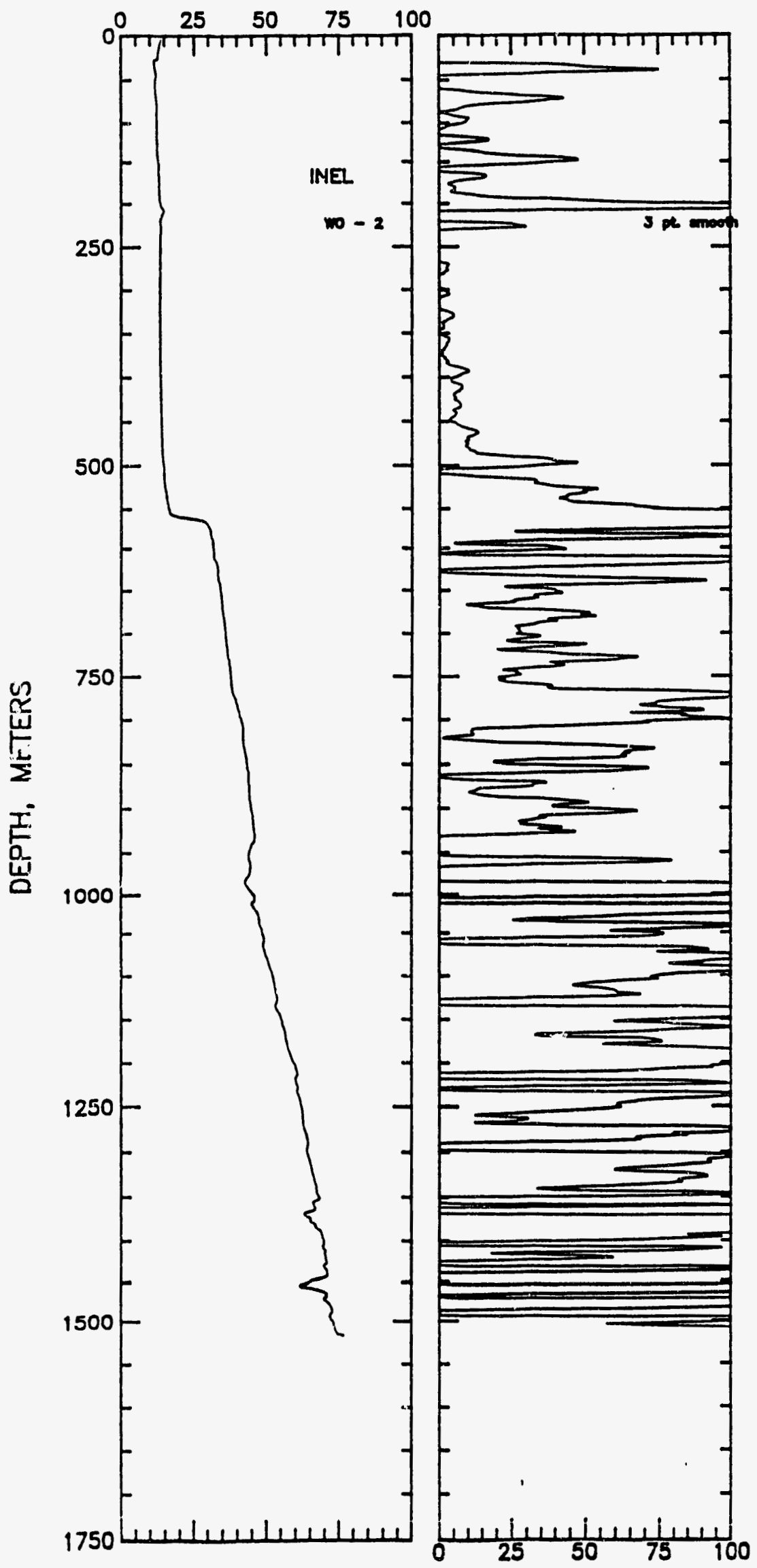



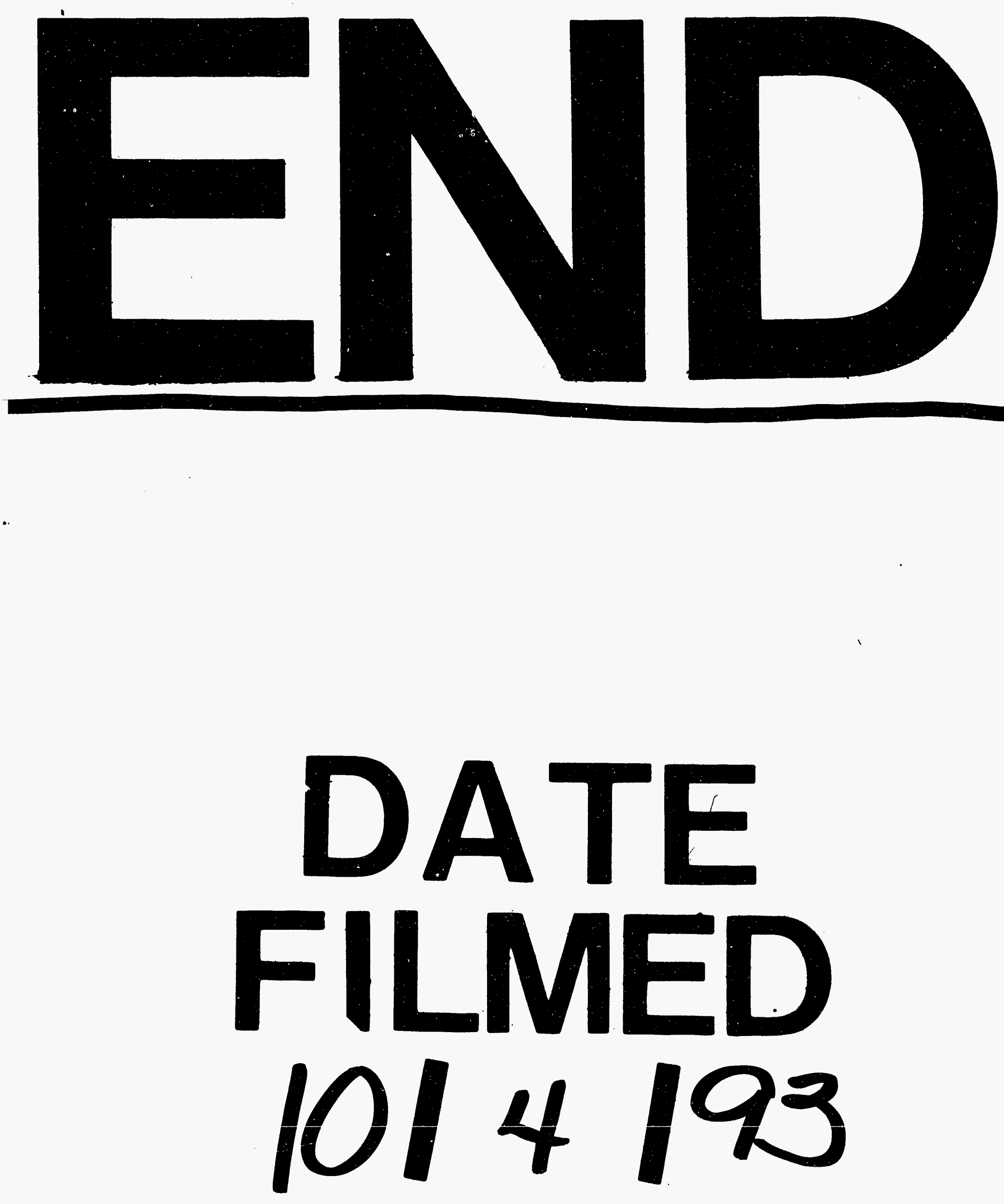
